\title{
Design and Application of Micro-class Platform for Engineering Training under Credit System
}

\author{
Cao Jianhua ${ }^{1,2}$ \\ ${ }^{1}$ Engineering Training Center, Wuhan University of Science \\ and Technology \\ ${ }^{2}$ Key Laboratory of Metallurgical Equipment and Control \\ Technology (Wuhan University of Science and Technology), \\ Ministry of Education \\ Wuhan 430081, China
}

\author{
Xia Xuhui* Wang Lei, \\ Key Laboratory of Metallurgical Equipment and Control \\ Technology (Wuhan University of Science and Technology), \\ Ministry of Education \\ Wuhan 430081, China
}

\author{
Liu Xiang ${ }^{1,2}$ \\ ${ }^{1}$ Engineering Training Center, Wuhan University of Science and Technology \\ ${ }^{2}$ Key Laboratory of Metallurgical Equipment and Control Technology (Wuhan University of Science and Technology), Ministry \\ of Education \\ Wuhan 430081, China
}

\begin{abstract}
In order to speed up the construction of online open courses and platforms suitable for practical training, we established a WeChat public platform based on the WeChat service platform, which integrates teaching management, micro-class, learning, innovation and competition. The platform fully embody and meet the individual needs of students and students can realize a series of learning processes such as independent online learning, self-selected training modules, self-scheduled practice time, online communication and answering questions. It will improve the effect of engineering training, and give better play to students' subjective initiative. It is more conducive to the students' independent learning, the cultivation of independent research and innovation ability and the development of individuality.
\end{abstract}

Keywords-Micro-class Platform; Engineering training; Credit System; Online Open Courses

\section{INTRODUCTION}

In recent years, new online open courses and learning platforms such as large-scale online open courses ("micro-class" and "MOOC") have rapidly emerged around the world, expanding the time and space of teaching, enhancing the attractiveness of teaching. It has stimulated the enthusiasm and autonomy of students, expanded the benefits of quality education resources, and is promoting changes in teaching content, methods, models and teaching management systems, bringing new opportunities and challenges to the reform and development of higher education ${ }^{[1-3]}$. Many scholars at home and abroad have conducted in-depth research on the application of micro-course teaching in mathematics ${ }^{[4-5]}$, English $^{[6-8]}$, biology ${ }^{[9-10]}$, information technology ${ }^{[11-12]}$ and other subjects. However, there are few studies on the design and application of the engineering training micro-class platform.

In view of the problem, this paper studies the construction and application of engineering training micro-class platform.
Establish a WeChat public platform based on the WeChat service number, which integrates teaching management, micro-courses, and learning and innovation and competition. The platform can fully reflect and meet the individual needs of students. Students can realize a series of learning processes such as independent online learning, self-selected training modules, self-scheduled practice time, online communication and answering questions, improve the effect of engineering training and better play the students' Subjective initiative is more conducive to students' independent learning, independent research and innovation ability cultivation and personality development.

\section{DESIGN OF PlatForm ARChITECTURE}

Under the credit system, the engineering training micro-class platform adopts a three-tier architecture, including user layer, application layer and data layer, as shown in Figure 1. The user layer accesses various applications in the application layer through the PC browser or the mobile terminal; the application layer interacts with the data layer through the Internet, the campus network support platform, the mobile micro-class platform, and the database unified description interface.

\section{A. User layer}

In the engineering training micro-course platform under the credit system, the user layer mainly has four types of users: students, teachers, administrators and tourists. Since different applications of the application layer are open to different types of users, in order to adapt to the access needs of different types of users, it is necessary to control access rights of different users.

In the design of user rights, the idea of Role-Based Access Control (RBAC) model is borrowed, and the user-role-operation relationship model is adopted. 
(1)User: Consistent with the definition in the RBAC model, the basic attributes of a specific visitor are defined.

(2)Role: According to the type of user, it is divided into four types: student, teacher, administrator and tourist. Different roles have different operating ranges and assume different responsibilities in the platform. Each role is associated with an operation in a specific module, and users in the same role have the same operational rights to a module.
(3)Operation: The specific operations in each business module in the system. The operations here are closely related to the business logic. These operations are generally process-oriented. Generally refers to the operation performed by a business process in a specific module. On the page, it is a collection of buttons or a group of buttons.

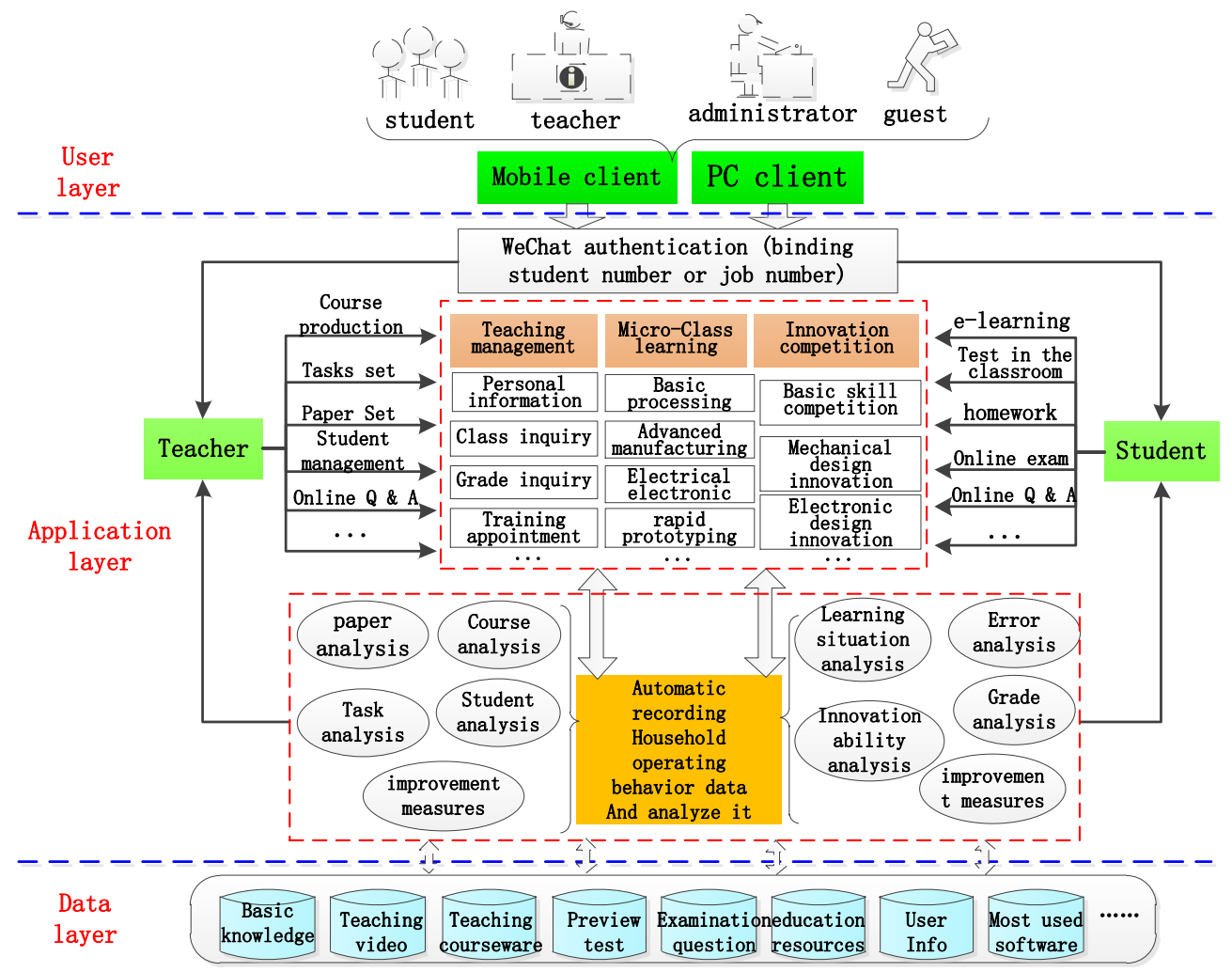

Fig. 1 Schematic diagram of the engineering training micro-class platform under the credit system

\section{B. Application layer}

The application layer provides various application services for the user layer, and is mainly composed of four modules: engineering training and teaching service platform, virtual simulation teaching platform, mobile micro-class platform and service platform management system. The first three modules are platforms for daily teaching and online learning services for students, teachers and visitors. The service platform management system provides administrators with online management and monitoring services for the entire system.

\section{Data layer}

The data layer stores various data submitted by the application layer and provides data support for the entire platform, including a basic knowledge base, a teaching video library, a teaching courseware library, a preview test question bank, a test test question library, a teaching resource information base, a user information base, The software information library and other modules are shown in Figure 2. 


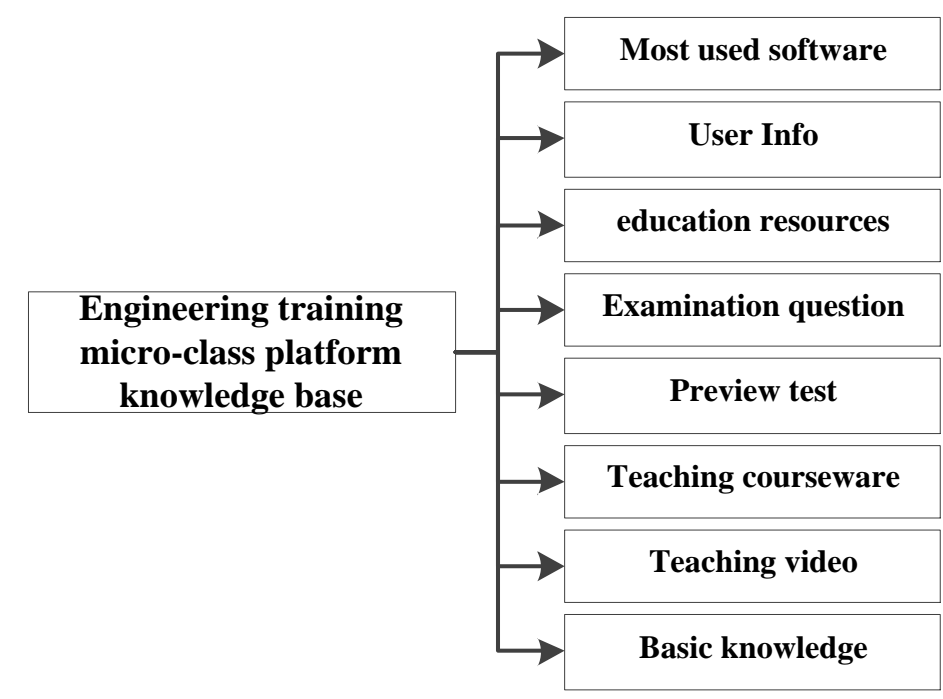

Fig. 2 Flow diagram of the engineering training service platform knowledge base.

\section{SYSTEM INTERFACE}

According to the design plan, based on the WeChat public platform, the engineering training micro-class platform of the Engineering Training Center of Wuhan University of Science and Technology was developed. The platform is mainly composed of the micro-platform management terminal and the client. The micro-platform management terminal is designed for the platform administrator and is mainly accessed through the PC, including system management functions such as user management and system configuration.

The micro-class platform is based on the WeChat public account. By scanning the QR code of the public number, pay attention to the WeChat work number of the Wuhan University of Science and Technology Engineering Training Center, and bind the WeChat public number to the student number/work number. The signal directly accesses the micro-course platform.

After entering the WeChat public account of the Engineering Training Center, you can view the relevant push information according to the prompts, or access the micro-platform through the menu bar below..

The micro-platform home page shows all the functions, mainly divided into two major modules: teaching management and job list. The teaching module is mainly related to the basic information management functions related to teaching, such as course selection, class schedule inquiry, performance inquiry, etc. The work type list is the relevant learning content divided by the engineering training center according to the type of work, such as ordinary car milling, fitter, CNC turning and milling. After clicking the corresponding micro-course learning menu, you can enter the micro-course video list page, where you can learn the micro-course video you are interested in.

\section{APPLICATION EFFECTS}

Through the application and practice of the engineering training micro-curriculum platform under the credit system, you can play the following roles in promoting teaching work and improving teaching quality:

(1) The engineering training under the credit system adopts a modular curriculum, organically integrates new technologies, new techniques and new methods in the field of modern manufacturing into classroom teaching, and rejects the traditional model in teaching methods, teaching content and teaching evaluation. Disadvantages provide a space for students' personality development. It can be seen that building a service-oriented engineering training model is an important means to improve the level of engineering training.

(2) Through the upgrade, transformation and update of engineering training hardware and information platform, realize the interaction between students and training WeChat platform, online training appointment service platform, training service teachers online and mobile interconnection, and realize traditional teaching. The mode shifts to a systematic, vivid and open innovative engineering training practice teaching method, thereby improving the effect of training and training.

(3)The contents of the engineering training teaching service module under the credit system are determined according to the professional characteristics of the students and the personal interest combination. The service implementation is based on the service teacher and is based on the micro-class platform, through the online construction and offline implementation. The type engineering training mode can effectively promote the structural adjustment of the teaching service team and improve the service teachers' ability. The construction of the service-oriented engineering training mode is an important measure for building a service-oriented high-level teaching team and an important link for establishing a new teacher-student relationship. 


\section{ACKNOWLEDGEMENT}

This research was financially supported by the Hubei Province Higher Education Teaching Research Project (2018254, 2018252);

Wuhan University of Science and Technology Teaching and Research Project (2017X062, 2018Z004, 2018X07, Yjg201801, 2018X072, 2019X085, 2019Z005).

\section{REFERENCES}

[1] Li Shaomei, Luo Wei. Design and Application of Micro-course in the Construction of Pre-school Education Curriculum in Normal Universities[J]. China Electro-chemical Education, 2015(11): 91-96.

[2] Li Ping. Reflections on the Application of Micro-curriculum to the Pre-service Training of Preschool Teachers in Colleges and Universities[J].Software Guide (Education Technology), 2017, 16(8): 60-61

[3] Li Shaomei. Thoughts on the application of micro-curriculum to the pre-service training of preschool teachers in colleges and universities[J]. Journal of Electrotechnical Education, 2016(8): 92-96.

[4] Sun Limei, Wu Hua. Teaching of Mathematics Micro-course Supported by Modern Information Technology[J]. Science and Technology Journal, 2013(35): 65-66.

[5] Song Zhuxi. Based on the teaching mode of micro-teaching, promoting the effectiveness of mathematics teaching in primary schools[J]. Mathematics Research and Research, 2017(24): 67-67.

[6] Liu Qi. How to Bring Micro-teaching Teaching into Junior Middle School English Teaching Classroom[J]. Education and Teaching Forum, 2017(30): 234-235.

[7] Feng Bizhen. Application of Micro-teaching Teaching Mode in College English Teaching[J]. Education Modernization, 2018, v.5(24): 119-120.

[8] Mao Yanli. Application of Micro-course in Young English Teaching[J]. Forum for Contemporary Education, 2015(3): 115-121.

[9] Liu Fucheng, Xiao Anqing, Li Ventil. Discussion on the teaching mode in the micro-study environment - Taking the application of micro-courses in high school biology teaching as an example[J]. China Modern Educational Equipment, 2014(2):58 -60.

[10] Liang Chunling. Application Research of Micro-class-based Flipping Classroom in Junior Middle School Biology Teaching — Taking Bacterial Course as an Example[J]. Education Information Technology, 2015(z2): 25-28.

[11] Zhu Wanglan. Micro-teaching Teaching Mode--New Thinking on Information Technology Teaching[J]. China Information Technology Education, 2014(8): 136-136.

[12] Wang Guohui. Analysis of the Application of Micro-course in the Teaching of Information Technology in Senior Middle School[J]. China Educational Technique \& Equipment, 2013(31): 94-95. 